\title{
Risk Factors of Antibiotic Misuse for Upper Respiratory Tract Infections in Children: Results from a Cross-Sectional Knowledge-Attitude-Practice Study in Greece
}

\author{
Sotiria G. Panagakou, ${ }^{1}$ Vassiliki Papaevangelou, ${ }^{2}$ Adamos Chadjipanayis, ${ }^{3}$ \\ George A. Syrogiannopoulos, ${ }^{4}$ Maria Theodoridou, ${ }^{5}$ and Christos S. Hadjichristodoulou ${ }^{1}$
}

${ }^{1}$ Department of Hygiene and Epidemiology, Faculty of Medicine, University of Thessaly, Thessaly, 41222 Larisa, Greece

${ }^{2}$ Second Department of Paediatrics, Aglaia Kyriakou Children's Hospital, University of Athens, 11527 Athens, Greece

${ }^{3}$ Paediatric Department, Larnaca General Hospital, 6043 Larnaca, Cyprus

${ }^{4}$ First Department of Pediatrics, Faculty of Medicine, University of Thessaly, 41110 Larisa, Greece

${ }^{5}$ Department of Paediatrics, Agia Sofia Children's Hospital, University of Athens, 11527 Athens, Greece

Correspondence should be addressed to Sotiria G. Panagakou, geopanagakos@yahoo.gr

Received 17 May 2012; Accepted 27 June 2012

Academic Editors: R. Bhimma, V. P. Choudhry, and G. D. Overturf

Copyright ( $) 2012$ Sotiria G. Panagakou et al. This is an open access article distributed under the Creative Commons Attribution License, which permits unrestricted use, distribution, and reproduction in any medium, provided the original work is properly cited.

\begin{abstract}
Background. Upper respiratory tract infections (URTIs) are common in children. The cause of URTIs is usually viral, but parents' attitudes often contribute to inappropriate prescription of antibiotics, promoting antibiotic resistance. The objective of this study was to identify possible risk factors associated with antibiotic misuse in Greece, a country with high levels of antibiotic use and antibiotic resistance. Methods. A knowledge-attitude-practice (KAP) questionnaire was developed and distributed to Greek parents caring for children who were 5-6 years old, between January and July of the same school year. Results. The sample of the study contained 5312 parents from all geographic areas of Greece. The risk factors of being a father, having low education, having immigrant status, being a single parent, having low income, having $<2$ or $>3$ children, living in the islands, and being without experience in recurrent URTIs were significantly associated to inadequate knowledge, inappropriate attitudes, and wrong practices. Conclusions. This study has identified the main groups of parents that should be targeted in future intervention programs.
\end{abstract}

\section{Introduction}

Upper respiratory tract infections (URTIs) in children are mainly due to viral infections $[1,2]$. Thus, the benefit from antimicrobial drugs is minimal. However, there is strong evidence that antibiotics are frequently administered to children suffering from URTIs $[3,4]$. It appears that both pediatricians and parents are responsible for this antibiotic misuse [5-7] which is contributing to the development of resistant strains of bacterial pathogens [8-10] and placing a burden on the economy of the health care system.

Amongst European countries, Greece presents the highest antibiotic consumption and antibiotic resistance [11]. In order to reveal the contributing factors of this phenomenon, a knowledge, attitude, and practice (KAP) study of Greek parents towards antibiotic use in children suffering from URTIs was performed. The objective of the current study was to identify possible risk factors associated with antibiotic misuse. This would enable the development of intervention strategies aiming to parental education.

\section{Materials and Methods}

2.1. Study Design and Settings. The study sample comprised of parents from all geographic areas of Greece. A school-based stratified geographic clustering sampling was used to select a representative sample of students. Seven thousand seven hundred and four parents (7704) of children aged between 5 and 6 years old participated 
in the survey. Approval was given by the Ministry of Education in order to contact the parents through the school system and to distribute anonymous questionnaires. Due to the anonymity of the questionnaire (available online at doi:10.5402/2012/685302 as supplementary material), written informed consent from parents was waived. The survey was conducted between January and July 2007. All methodological aspects of the study, including the sampling, designdevelopment-completeness-reliability of the questionnaire, and any limitations which emerged, have been presented in previous papers $[12,13]$.

In the current study an effort was made to identify risk factors associated with injudicious antibiotic use. To accomplish this aim, a subsample of questions which suggested antibiotic misuse from each section was selected. Therefore, to increase the sensitivity of our survey, three groups of questions were formed: questions Q17, Q18, Q19 and Q22 (knowledge section), Q30, Q31, Q32, Q34, (attitude section), and questions Q42, Q45, Q46 (practice section). The questionnaire has been added as an annexure in the manuscript. Parents giving an incorrect answer to any of the questions included in a group were considered as being erroneous in their response for the entire group of questions. Additionally, questions Q16 (knowledge section), Q27, and Q28 (attitude section) were examined separately since they contained a number of subquestions. Whether specific parental demographic characteristics are associated with incorrect answering to the selected questions was examined. In order to assess the quality of the results obtained with the method described above, we also combined the questions in scales in order to give overall attitude, knowledge, and practice scores. The scores were afterwards associated with parental demographic characteristics.

2.2. Data Analysis. The data was entered into a database using the Epi Info program. Statistical Package for Social Sciences (SPSS) version 15.0 was used to analyze data from the questionnaire. Chi-square test and Kruskal-Wallis test were used to assess statistical significant correlations between the variables. Ninety-five percent confidence intervals were calculated for relative risks. The level of significance was 0.05 .

Backward logistic regression was used to identify independent factors associated to injudicious antibiotic use. During backward logistic regression in the 5-point Likert scales, the answers "strongly agree" and "agree" were considered as a "positive" answer, while the answers "disagree" and "strongly disagree" were considered as a "negative" answer. The answer "uncertain" was not taken into consideration. The answers "always," "most of the times," and "often" were considered as "frequently", while the answers "sometimes" and "never" were considered as "rarely."

\section{Results}

Five thousand three hundred and twelve questionnaires were collected out of 7704 that were initially disseminated, representing a response rate of $68.95 \%$. Tables 1,2 , and 3 show the percentile number of the parents who gave wrong answers to the selected questions in the sections of knowledge, attitude, and practices, respectively, according to the univariate analysis.

Table 4 describes the results of the backward logistic regression analysis performed. The risk factors of father, low education, and immigrant status were detected as significantly associated for all the sections (knowledge-attitudespractices). Additional risk factors were revealed in the knowledge section when the latter was examined separately (parents living in the islands, having low income, $<2$ or $>3$ children, and no experience in recurrent URTIs) while questions from the attitude section were significantly related additionally to the demographic characteristics of being a single parent and having no experience in recurrent URTIs. The same results were derived even when we combined the questions in scales in order to give overall attitude, knowledge, and practice scores (data not shown).

\section{Discussion}

Even though it has been widely recognized that URTIs are the most often of viral etiology [14] and clinical practice guidelines for their management are well established, still antibiotics are prescribed for children with URTIs [15-18]. Greece is one of the countries with the highest antibiotic consumption in Europe [11]. Additionally, a recent European Commission report indicated that Greece also has the highest over the counter antibiotic sales amongst $27 \mathrm{EU}$ countries [19]. In Greece, parents have free access to all types of ordinary antibiotics despite a specific legislation forbidding antibiotic use without a prescription. In a recent survey that took place in the capital of Greece, Athens, volunteers presented to pharmacies asking for ciprofloxacin and coamoxiclav to document if it is possible to obtain antibiotics without a prescription [20]. Co-amoxiclav was given in 100\% of cases while ciprofloxacin was given in $53 \%$, pointing by this way out the extent of just one aspect of antibiotic misuse. Our study [13] has shown that over-the-counter use was very low but it is unclear how this reflects real-life practice.

Since there is evidence indicating that antibiotic overuse drives bacterial resistance, [8-10] the identification of factors influencing antimicrobial prescription in pediatric practice may have a considerable public health impact. This is the first population-based KAP study of Greek parents and the current paper aims to describe parental risk factors associated with antibiotic overuse in Greece.

This study was able to portray the demographic profile of parents prone to antibiotic misuse. The main parental demographic characteristics associated with antibiotic misuse include being a father, having low educational level, and being an immigrant.

There have been several studies indicating a positive relationship between parental educational level and their expected knowledge about antibiotic treatment [21-23]. It is probable that low education is related to inadequate information about judicious antibiotic use which can lead to improper practices $[22,24]$. Indeed, as shown in Tables 2,3 , and 4 , parental educational level is inversely related 
TABLE 1: Parents (\%) who did not answer correctly in the selected questions of the knowledge section.

\begin{tabular}{|c|c|c|c|c|}
\hline & Q15 & $P$ value & Q17, Q18, Q19, Q22 & $P$ value \\
\hline Athens & 8.4 & $0.004^{*}$ & 1.7 & $0.004^{*}$ \\
\hline Northern Greece & 9.7 & & 1.9 & \\
\hline Central Greece & 9.2 & & 3.1 & \\
\hline Islands versus & 13.9 & & 3.8 & \\
\hline Peloponnese & 9.1 & & 1.3 & \\
\hline Mothers & 6.9 & $<0.001^{*}$ & 1.6 & $<0.001^{*}$ \\
\hline Fathers & 19 & & 4.1 & \\
\hline $31-45$ years & 9.1 & $<0.001^{*}$ & 1.9 & $0.006^{*}$ \\
\hline$<31$ or $>45$ years & 13.5 & & 3.5 & \\
\hline \multicolumn{5}{|l|}{ Insurance } \\
\hline Public & 9.4 & $0.001^{*}$ & 2.1 & 0.29 \\
\hline Private & 16.3 & & 1.7 & \\
\hline Public and private & 8.3 & & 2.6 & \\
\hline None & 31.3 & & 12.5 & \\
\hline \multicolumn{5}{|l|}{ Education of father } \\
\hline Primary school & 17 & $<0.001^{*}$ & 4.3 & $<0.001^{*}$ \\
\hline Secondary school & 15.7 & & 2.9 & \\
\hline High school & 9.3 & & 1.9 & \\
\hline College & 5.3 & & 1.5 & \\
\hline University & 4.1 & & 0.5 & \\
\hline \multicolumn{5}{|l|}{ Education of mother } \\
\hline Primary school & 24.4 & $<0.001^{*}$ & 7.9 & $<0.001^{*}$ \\
\hline Secondary school & 22.6 & & 4.6 & \\
\hline High school & 8.8 & & 2.1 & \\
\hline College & 4.1 & & 0.8 & \\
\hline University & 4.3 & & 0.5 & \\
\hline \multicolumn{5}{|l|}{ Income $^{\wedge}$} \\
\hline High & 5.6 & $<0.001^{*}$ & 1.3 & $<0.001^{*}$ \\
\hline Moderate & 8.5 & & 2 & \\
\hline Low & 18.8 & & 4.3 & \\
\hline Immigrants & 35.9 & $<0.001^{*}$ & 10.3 & $<0.001^{*}$ \\
\hline Nonimmigrants & 6.7 & & 1.3 & \\
\hline \multicolumn{5}{|l|}{ Residence } \\
\hline Big Towns & 8.8 & $0.002^{*}$ & 2.2 & 0.773 \\
\hline Small Towns & 10.3 & & 2 & \\
\hline Villages & 13.1 & & 2.4 & \\
\hline \multicolumn{5}{|l|}{ Number of children } \\
\hline $2-3$ & 8.7 & $<0.001^{*}$ & 2.2 & 0.513 \\
\hline$<2 \dot{\eta}>3$ & 13.4 & & 2.2 & \\
\hline Couples & 9.4 & 0.217 & 2.1 & 0.056 \\
\hline Singles & 11 & & 3.7 & \\
\hline \multicolumn{5}{|c|}{ Experience of recurrent URIs } \\
\hline Yes & 4.2 & $<0.001^{*}$ & 2.5 & 0.256 \\
\hline No & 10.6 & & 2.1 & \\
\hline \multicolumn{5}{|c|}{ Pediatrician-parent relation } \\
\hline Friends or relatives & 8.3 & $0.009^{*}$ & 2 & 0.318 \\
\hline Typical & 10.6 & & 2.2 & \\
\hline \multicolumn{5}{|c|}{ Access to healthcare system } \\
\hline Good & 11.5 & $<0.001^{*}$ & 3 & $0.003^{*}$ \\
\hline Moderate & 8.4 & & 1.6 & \\
\hline Poor & 5.7 & & 1.2 & \\
\hline
\end{tabular}

Bold letters and ${ }^{*}$ : variables with elevated level of significance after univariate analysis.

Income ${ }^{\wedge}$ : self-assessment as perceived by the parents at the time of the survey. 
TABLE 2: Parents (\%) who did not answer correctly in the selected questions of the attitude section.

\begin{tabular}{|c|c|c|c|c|c|c|}
\hline & Q27 & $P$ value & Q28 & $P$ value & Q30, Q31, Q32, Q34 & $P$ value \\
\hline Athens & 31.7 & $0.000^{*}$ & 6.7 & 0.154 & 0.2 & 0.106 \\
\hline Northern Greece & 36.6 & & 6 & & 0.2 & \\
\hline Central Greece & 44.2 & & 7.5 & & 0.4 & \\
\hline Islands versus & 38.8 & & 7.9 & & 0.6 & \\
\hline Peloponnese & 35.8 & & 5.1 & & 0 & \\
\hline Mothers & 35.7 & $0.005^{*}$ & 5.4 & $<0.001^{*}$ & 0.2 & 0.414 \\
\hline Fathers & 40.2 & & 10.5 & & 0.3 & \\
\hline $31-45$ years & 35.7 & $<0.001^{*}$ & 6.2 & $0.015^{*}$ & 0.2 & 0.293 \\
\hline$<31$ or $>45$ years & 41.9 & & 8.3 & & 0.4 & \\
\hline \multicolumn{7}{|l|}{ Insurance } \\
\hline Public & 37.2 & $0.049^{*}$ & 6.4 & 0.779 & 0.3 & 0.467 \\
\hline Private & 32.5 & & 5.7 & & 0 & \\
\hline Public and private & 34.3 & & 6.5 & & 0 & \\
\hline None & 62.5 & & 12.5 & & 0 & \\
\hline \multicolumn{7}{|l|}{ Education of father } \\
\hline Primary school & 45 & $<0.001^{*}$ & 12 & $<0.001^{*}$ & 0.3 & 0.572 \\
\hline Secondary school & 41 & & 9.1 & & 0.3 & \\
\hline High school & 36.9 & & 5.8 & & 0.2 & \\
\hline College & 33.6 & & 5 & & 0.1 & \\
\hline University & 31.8 & & 3.9 & & 0 & \\
\hline \multicolumn{7}{|l|}{ Education of mother } \\
\hline Primary school & 45.2 & $<0.001^{*}$ & 14.4 & $<0.001^{*}$ & 0.3 & 0.398 \\
\hline Secondary school & 44.4 & & 10.1 & & 0.3 & \\
\hline High school & 36.8 & & 5.9 & & 0.4 & \\
\hline College & 34.8 & & 4.7 & & 0.1 & \\
\hline University & 31.9 & & 4.7 & & 0.1 & \\
\hline \multicolumn{7}{|l|}{ Income $^{\wedge}$} \\
\hline High & 33.5 & $<0.001^{*}$ & 5 & $<0.001^{*}$ & 0.1 & 0.626 \\
\hline Moderate & 35.8 & & 6.1 & & 0.2 & \\
\hline Low & 44.7 & & 11.2 & & 0.4 & \\
\hline Immigrants & 55.8 & $<0.001^{*}$ & 18.3 & $<0.001^{*}$ & 1.2 & $0.000^{*}$ \\
\hline Nonimmigrants & 34.7 & & 5.2 & & 0.1 & \\
\hline \multicolumn{7}{|l|}{ Residence } \\
\hline Big Towns & 36.1 & 0.271 & 6.4 & 0.625 & 0.2 & 0.946 \\
\hline Small Towns & 37.6 & & 6.5 & & 0.2 & \\
\hline Villages & 39.1 & & 7.4 & & 0.3 & \\
\hline \multicolumn{7}{|l|}{ Number of children } \\
\hline $2-3$ & 36.8 & 0.413 & 6 & $0.009^{*}$ & 0.2 & 0.299 \\
\hline$<2 \dot{\eta}>3$ & 36.4 & & 8 & & 0.3 & \\
\hline Couples & 36.4 & $0.043^{*}$ & 6.3 & $0.033^{*}$ & 0.2 & 0.494 \\
\hline Singles & 41.5 & & 9.3 & & 0 & \\
\hline \multicolumn{7}{|c|}{ Experience of recurrent URIs } \\
\hline Yes & 40.9 & $0.005^{*}$ & 6.3 & 0.478 & 0.1 & 0.53 \\
\hline No & 36 & & 6.5 & & 0.2 & \\
\hline \multicolumn{7}{|c|}{ Pediatrician-parent relation } \\
\hline Friends or relatives & 37.1 & 0.263 & 6 & 0.057 & 0.3 & 0.449 \\
\hline Typical & 38.2 & & 7.4 & & 0.2 & \\
\hline \multicolumn{7}{|c|}{ Access to healthcare system } \\
\hline Good & 39 & $0.016^{*}$ & 7.3 & $0.038^{*}$ & 0.2 & 0.895 \\
\hline Moderate & 35.2 & & 5.4 & & 0.3 & \\
\hline Poor & 34.5 & & 7 & & 0.2 & \\
\hline
\end{tabular}

Bold letters and ${ }^{*}$ : variables with elevated level of significance after univariate analysis.

Income ${ }^{\wedge}$ : self-assessment as perceived by the parents at the time of the survey. 
TABle 3: Parents (\%) who did not answer correctly in the selected questions of the practice section.

\begin{tabular}{|c|c|c|}
\hline & Q42, Q45, Q46 & $P$ value \\
\hline Athens & 25.5 & $0.005^{*}$ \\
\hline Northern Greece & 22.5 & \\
\hline Central Greece & 27.5 & \\
\hline Islands versus & 24.5 & \\
\hline Peloponnese & 20.2 & \\
\hline Mothers & 22.5 & $<0.001^{*}$ \\
\hline Fathers & 28.8 & \\
\hline $31-45$ years & 23.1 & $0.002^{*}$ \\
\hline$<31$ or $>45$ years & 28 & \\
\hline \multicolumn{3}{|l|}{ Insurance } \\
\hline Public & 23.5 & 0.372 \\
\hline Private & 22 & \\
\hline Public and private & 25.4 & \\
\hline None & 37.5 & \\
\hline \multicolumn{3}{|l|}{ Education of father } \\
\hline Primary school & 30.5 & $<0.001^{*}$ \\
\hline Secondary school & 26.7 & \\
\hline High school & 23.9 & \\
\hline College & 22.7 & \\
\hline University & 19.6 & \\
\hline \multicolumn{3}{|l|}{ Education of mother } \\
\hline Primary school & 36.9 & $<0.001^{*}$ \\
\hline Secondary school & 29 & \\
\hline High school & 25.5 & \\
\hline College & 19.3 & \\
\hline University & 19.7 & \\
\hline \multicolumn{3}{|l|}{ Income $^{\wedge}$} \\
\hline High & 22.6 & $0.001^{*}$ \\
\hline Moderate & 23.2 & \\
\hline Low & 30.5 & \\
\hline Immigrants & 43.7 & $<0.001^{*}$ \\
\hline Nonimmigrants & 21.8 & \\
\hline \multicolumn{3}{|l|}{ Residence } \\
\hline Big Towns & 23.7 & 0.661 \\
\hline Small Towns & 24.8 & \\
\hline Villages & 23.2 & \\
\hline \multicolumn{3}{|l|}{ Number of children } \\
\hline $2-3$ & 23.7 & 0.25 \\
\hline$<2 \dot{\eta}>3$ & 24.7 & \\
\hline Couples & 23.8 & 0.355 \\
\hline Singles & 24.9 & \\
\hline \multicolumn{3}{|c|}{ Experience of recurrent URIs } \\
\hline Yes & 22.2 & 0.132 \\
\hline No & 24.1 & \\
\hline \multicolumn{3}{|c|}{ Pediatrician-parent relation } \\
\hline Friends or relatives & 26.1 & 0.052 \\
\hline Typical & 23.7 & \\
\hline
\end{tabular}

TABle 3: Continued.

\begin{tabular}{lcc}
\hline & Q42, Q45, Q46 & $P$ value \\
\hline Access to healthcare system & & \\
Good & $\mathbf{2 4 . 8}$ & $\mathbf{0 . 0 2 8}^{*}$ \\
Moderate & 23.4 & \\
Poor & 19.5 & \\
\hline
\end{tabular}

Bold letters and $*$ : variables with elevated level of significance after univariate analysis.

Income $^{\wedge}$ : self-assessment as perceived by the parents at the time of the survey.

to the percentage of parents answering incorrectly. Limited access to Internet, other media, or literature among poorly educated parents maybe related to reduced source availability concerning antibiotic consumption. On the contrary, parents with higher educational status seem to better acknowledge the risks of antibiotic misuse, making pediatricians more skeptical to offer antibiotic treatment [25]. Furthermore, being an immigrant was associated with antibiotic misuse. In Greece, minorities represent more than $10 \%$ of population and a similar percentage was assessed among the participants in the study (10\%). The vast majority of immigrants in Greece are of low socioeconomic status, possibly explaining their pressure for antibiotic therapy as aforementioned. In addition, being away from homeland often causes uncertainty and high worry of a child's illness, leading to antibiotic demand. Moreover, as many immigrants are not fluent in Greek, it is possible that miscommunication among parents and pediatricians in reference to medical history and proper treatment may also contribute to increased antibiotic consumption [26]. Finally, cultural beliefs vary among minorities. Mangione-Smith et al. in Los Angeles found that non-Hispanic white parents were less likely to expect antibiotics than Latino, Asian, and African American parents [26]. Other studies have reported the immigrant status as being a positive predictor of receiving an antibiotic prescription too $[24,27,28]$.

Interestingly, a strong risk factor associated with all the three sections of the questionnaire was being a father. One could postulate that Greek fathers do not participate as much as mothers in upbringing their children and therefore they may be less inclined to research information concerning medical matters. Fathers' participation in the daily care of their children has significantly changed over the past decades due to the increase in the number of women entering the labor force, the increase of one-parent families, the decrease of married couples, the decrease in the number of children in nuclear families, and the spread of the child-centered ideology [29]. However, in a recent study among Greek fathers, there was evidence that fathers from rural areas with low academic achievements and occupational status are less likely to contribute to child care practices than fathers living in urban areas with high educational and occupational status [30]. To our knowledge, such correlation has not been mentioned in other studies and could be due to cultural issues. 


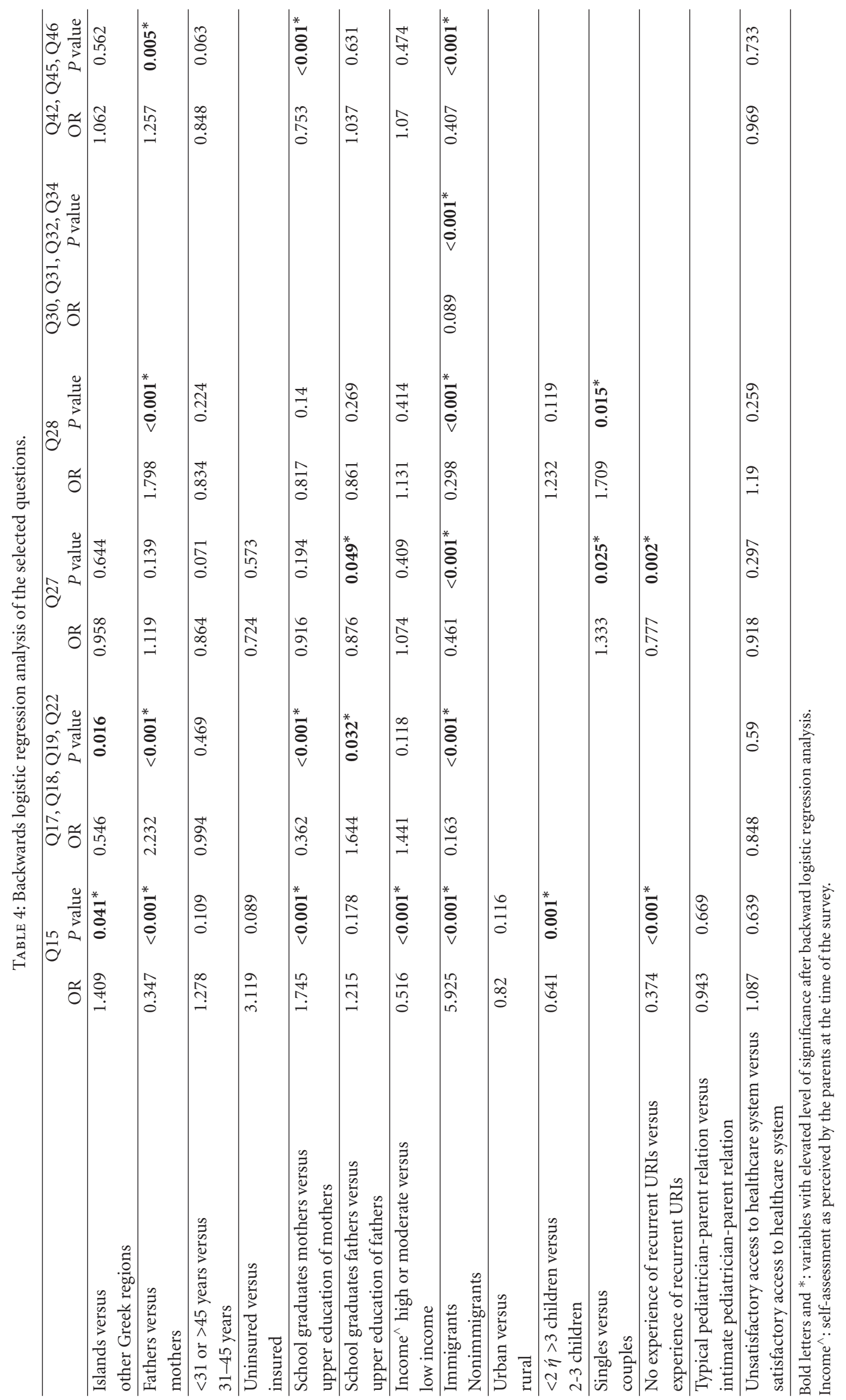


Additional risk factors were detected in the knowledge and attitude section. Single parents reported improper attitudes concerning antibiotic use. As it has also been acknowledged $[25,31]$ that it is more difficult to take care of a sick child in single-parent families, especially if other relatives are not available. Thus, one could speculate that single parents expect antibiotic treatment assuming that it will shorten disease duration and therefore allowing them to return to their workplace earlier. As expected, limited parental experience to recurrent URTIs was also found to be a determinant of antibiotic misuse. Probably as parents get exposed to more incidents of URTIs, their chance to receive education concerning judicious antibiotic use increases.

Moreover, island inhabitants tended to give incorrect answers. Greek geographical area contains several islands, most of which suffer from a weak healthcare network, which is most likely unable to properly educate the inhabitants about antibiotic misuse. Moreover, in many islands, access to hospitals is difficult, which is increasing pediatricians' anxiety and their prescribing antibiotics for fear of possible secondary complications after a URTI.

Low income was also described as a risk factor driving to antibiotic misuse. Low educational status can often be related to low household income as depicted in other studies [31, 32]. In addition, jobs with lower reimbursement usually have less working hours flexibility, discouraging parents to spend time with their sick child at home and therefore leading them to administer antibiotic therapy in hope that the child will recover quicker and let them return to work [32].

Finally, having either one or more than three children was associated with poor antibiotic knowledge. Kuzujanakis et al. also associated adequate antibiotic knowledge with having $>1$ child [28]. It was suggested that parents gain experience concerning antibiotic use when dealing with more than one child. However, it is difficult to explain why parents with more than 3 children presented poor antibiotic knowledge scores. One could postulate, that families with $>3$ children tend to be of low socioeconomic status although no such evidence has been reported elsewhere.

However, amongst various studies that have been held in other countries, additional risk factors had been identified. Parental age has been reported as a factor affecting antibiotics expectation [25, 28], as well as the type of insurance [27]. Even though in our study these factors were included in the demographic characteristics and were elaborated through analysis, significant statistical association after the logistic regression analysis was not observed. Finally, in our study, parents reporting a typical relationship with their pediatrician were not more likely to provide incorrect answers but often failed to identify common antibiotic names.

An effort was made to identify the limitations of this study. The survey was conducted from January to June. Winter and spring seasons are generally associated with an increased likelihood of URTIs and therefore antibiotic prescriptions, therefore parents may have reported an overestimating practice of antibiotic overuse. Another limitation concerns the assertion on parents' self-report about their knowledge, attitude, and practices towards antibiotic use. As parents were informed that this questionnaire was used for a study, they might have been reluctant to report practices that could be considered inappropriate. An additional limitation of the study refers to the language and medical terms used when designing the questionnaire. Although an effort was made to use simple words, parents with lowest education and immigrants might have been unable to comprehend the questionnaire.

This study has identified the main groups of parents to which intervention programs should aim. Thus, in Greece, future campaigns should be targeting mostly parents of low educational status, immigrants and fathers. However the role of pediatricians themselves in reducing antibiotic misuse should not be underestimated. In fact, our study [13] showed that parents play a much lesser role than paediatricians on antibiotic overuse, indicating that determining what doctors practice for URTI treatment is probably the key to tackle this major issue, as also described in intervention programs [33]. Therefore, such campaigns should focus on educating parents and paediatricians as well about the role of antibiotics, the cost effectiveness of their administration, and the significant problem of antibiotic resistance in the community.

\section{Conflict of Interests}

The authors declare no conflict of interests.

\section{Acknowledgments}

This research was supported by the Ministry of Education and by the Medical School of University of Thesally. The authors would like to thank the directors and the teachers of the schools that participated in the study for their cooperation. The authors acknowledge the valuable contribution of G. Panagakos and A. Katsioulis in developing the necessary software, as well as for their assistance with data management, analysis, and interpretation of the data.

\section{References}

[1] A. L. Nordlie and B. M. Andersen, "Parents' attitudes to the prescription of antibiotics to children," Tidsskrift for den Norske Laegeforening, vol. 124, no. 17, pp. 2229-2231, 2004.

[2] J. C. Buñuel Álvarez, E. Fortea Gimeno, R. B. Cortés Marina, C. Vila Pablos, F. Blanch Risec, and M. Estany Delgado, "Antibiotic use in primary care. Do we know what parents think?" Anales de Pediatria, vol. 61, no. 4, pp. 298-304, 2004.

[3] E. Paluck, D. Katzenstein, C. J. Prankish et al., "Prescribing practices and attitudes toward giving children antibiotics," Canadian Family Physician, vol. 47, pp. 521-527, 2001.

[4] J. C. Pechère, "Patients' interviews and misuse of antibiotics," Clinical Infectious Diseases, vol. 33, no. 3, pp. S170-S173, 2001.

[5] R. Mangione-Smith, E. A. McGlynn, M. N. Elliott, L. McDonald, C. E. Franz, and R. L. Kravitz, "Parent expectations for antibiotics, physician-parent communication, and satisfaction," Archives of Pediatrics and Adolescent Medicine, vol. 155, no. 7, pp. 800-806, 2001.

[6] R. L. Watson, S. F. Dowell, M. Jayaraman, H. Keyserling, M. Kolczak, and B. Schwartz, "Antimicrobial use for pediatric 
upper respiratory infections: reported practice, actual practice, and parent beliefs," Pediatrics, vol. 104, no. 6, pp. 12511257, 1999.

[7] L. F. McCaig, R. E. Besser, and J. M. Hughes, "Trends in antimicrobial prescribing rates for children and adolescents," Journal of the American Medical Association, vol. 287, no. 23, pp. 3096-3102, 2002.

[8] A. Harnden, R. Perera, A. B. Brueggemann et al., "Respiratory infections for which general practitioners consider prescribing an antibiotic: a prospective study," Archives of Disease in Childhood, vol. 92, no. 7, pp. 594-597, 2007.

[9] R. Mangione-Smith, M. N. Elliott, T. Stivers, L. McDonald, J. Heritage, and E. A. McGlynn, "Racial/ethnic variation in parent expectations for antibiotics: implications for public health campaigns," Pediatrics, vol. 113, no. 5, pp. e385-e394, 2004.

[10] H. Bauchner, S. I. Pelton, and J. O. Klein, "Parents, physicians, and antibiotic use," Pediatrics, vol. 103, no. 2, pp. 395-401, 1999.

[11] Total Outpatient Antibiotic Use (ATC J01) in 27 European Countries, ECDC, 2006 http://www.ecdc.europa.eu/.

[12] S. G. Panagakou, M. N. Theodoridou, V. Papaevangelou et al., "Development and assessment of a questionnaire for a descriptive cross-sectional study concerning parents' knowledge, attitudes and practices in antibiotic use in Greece," BMC Infectious Diseases, vol. 9, article 52, 2009.

[13] S. G. Panagakou, I. Spyridis, V. Papaevangelou et al., "Antibiotic use for upper respiratory tract infections in children: a cross-sectional survey of knowledge, attitudes, and practices (KAP) of parents in Greece," BMC Pediatrics, vol. 11, article 60, 2011.

[14] A. W. Sturm, R. Van Der Pol, A. J. Smits et al., "Over-thecounter availability of antimicrobial agents, self-medication and patterns of resistance in Karachi, Pakistan," Journal of Antimicrobial Chemotherapy, vol. 39, no. 4, pp. 543-547, 1997.

[15] N. Rosenstein, W. R. Phillips, M. A. Gerber, S. M. Marcy, B. Schwartz, and S. F. Dowell, "The common cold-principles of judicious use of antimicrobial agents," Pediatrics, vol. 101, no. 1, supplement, pp. 181-184, 1998.

[16] K. L. O’Brien, S. F. Dowell, B. Schwartz, S. M. Marcy, W. R. Phillips, and M. A. Gerber, "Cough illness/bronchitisprinciples of judicious use of antimicrobial agents," Pediatrics, vol. 101, no. 1, pp. 178-181, 1998.

[17] S. F. Dowell, S. M. Marcy, W. R. Phillips, M. A. Gerber, and B. Schwartz, "Otitis media-principles of judicious use of antimicrobial agents," Pediatrics, vol. 101, no. 1, pp. 165-171, 1998.

[18] A. L. Kozyrskyj, G. E. Hildes-Ripstein, S. E. A. Longstaffe et al., "Treatment of acute otitis media with a shortened course of antibiotics: a meta-analysis," Journal of the American Medical Association, vol. 279, no. 21, pp. 1736-1742, 1998.

[19] R. Watson, "More than 15\% of antibiotic sales in Greece are over the counter," British Medical Journal, vol. 340, article c2143, 2010.

[20] D. Plachouras, D. Kavatha, A. Antoniadou et al., "Dispensing of antibiotics without prescription in Greece, 2008: another link in the antibiotic resistance chain," Eurosurveillance, vol. 15, no. 7, pp. 1-4, 2010.

[21] A. Al Tenaiji, J. Al Mutawa, K. Al Redha et al., "Knowledge, attitudes and behavior towards Antibiotic Use among Parents in Al Ain," in Proceedings of the 1st Annual Student Research Symposium Faculty of Medicine and Health Sciences, U.A.E. University, 2006.
[22] K. Kleinman, S. Rifas-Shiman, and J. A. Finkelstein, "Correlates of parental antibiotic knowledge, demand, and reported use," Ambulatory Pediatrics, vol. 3, no. 4, pp. 203-210, 2003.

[23] V. Shlomo, R. Adi, and K. Eliezer, "The knowledge and expectations of parents about the role of antibiotic treatment in upper respiratory tract infection-a survey among parents attending the primary physician with their sick child," $B M C$ Family Practice, vol. 4, article 20, 2003.

[24] S. R. Arnold, T. To, W. J. McIsaac, and E. E. L. Wang, "Antibiotic prescribing for upper respiratory tract infection: the importance of diagnostic uncertainty," Journal of Pediatrics, vol. 146, no. 2, pp. 222-226, 2005.

[25] B. L. Braun and J. B. Fowles, "Characteristics and experiences of parents and adults who want antibiotics for cold symptoms," Archives of Family Medicine, vol. 9, no. 7, pp. 589-595, 2000.

[26] R. Mangione-Smith, M. N. Elliott, T. Stivers, L. McDonald, J. Heritage, and E. A. McGlynn, "Racial/ethnic variation in parent expectations for antibiotics: implications for public health campaigns," Pediatrics, vol. 113, no. 5, pp. e385-e394, 2004.

[27] E. Ladd, "The use of antibiotics for viral upper respiratory tract infections: an analysis of nurse practitioner and physician prescribing practices in ambulatory care, 1997-2001," Journal of the American Academy of Nurse Practitioners., vol. 17, no. 10, pp. 416-424, 2005.

[28] M. Kuzujanakis, K. Kleinman, S. Rifas-Shiman, and J. A. Finkelstein, "Correlates of parental antibiotic knowledge, demand, and reported use," Ambulatory Pediatrics, vol. 3, no. 4, pp. 203-210, 2003.

[29] C. Lewis, "Fathers and preschoolers," in The Role of the Father in Child Development, M. E. Lamb, Ed., pp. 121-142, Wiley, New York, NY, USA, 3rd edition, 1997.

[30] K. Maridaki-Kassotaki, "Understanding fatherhood in Greece: father's involvement in child care," Psicologia: Teoria $e$ Pesquisa, vol. 16, no. 3, pp. 213-219, 2000.

[31] N. Thrane, C. Olesen, H. C. Schønheyder, and H. T. Sørensen, "Socioeconomic factors and prescription of antibiotics in 0- to 2-year-old Danish children," Journal of Antimicrobial Chemotherapy, vol. 51, no. 3, pp. 683-689, 2003.

[32] A. L. Kozyrskyj, M. E. Dahl, D. G. Chateau, G. B. Mazowita, T. P. Klassen, and B. J. Law, "Evidence-based prescribing of antibiotics for children: role of socioeconomic status and physician characteristics," Canadian Medical Association Journal, vol. 171, no. 2, pp. 139-145, 2004.

[33] V. Papaevangelou, A. Rousounides, A. Hadjipanagis, A. Katsioulis, M. Theodoridou, and C. Hadjichristodoulou, "Decrease of antibiotic consumption in children with upper respiratory tract infections after implementation of an intervention program in cyprus," Antimicrobial Agents and Chemotherapy, vol. 56, no. 3, pp. 1658-1661, 2012. 


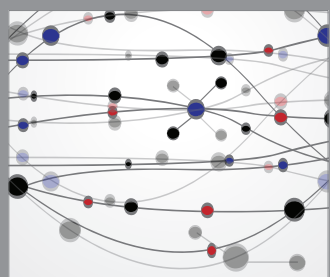

The Scientific World Journal
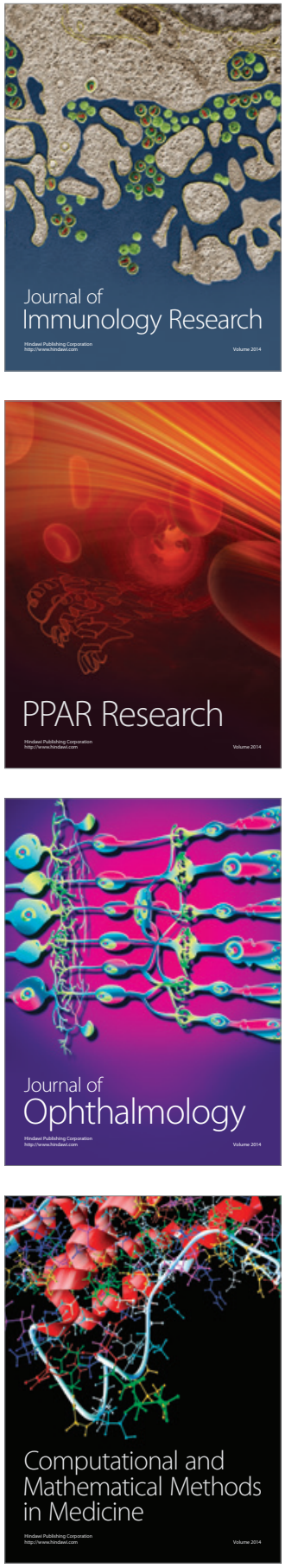

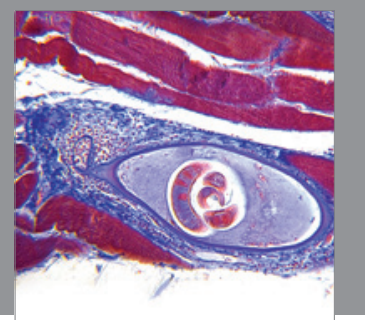

Gastroenterology

Research and Practice
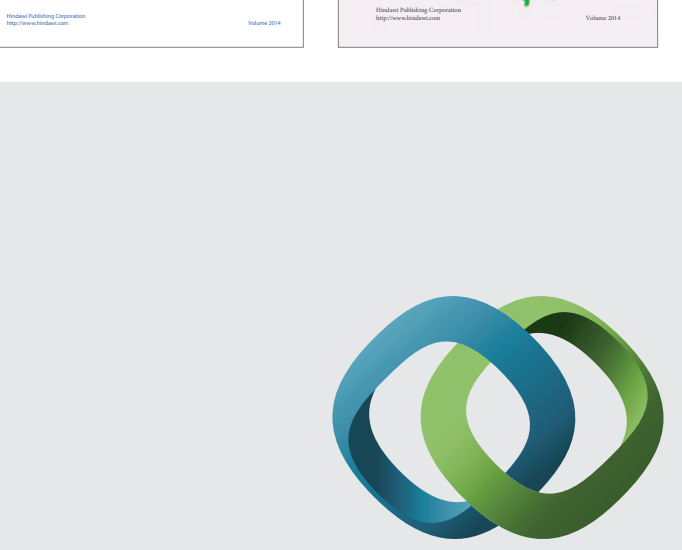

\section{Hindawi}

Submit your manuscripts at

http://www.hindawi.com
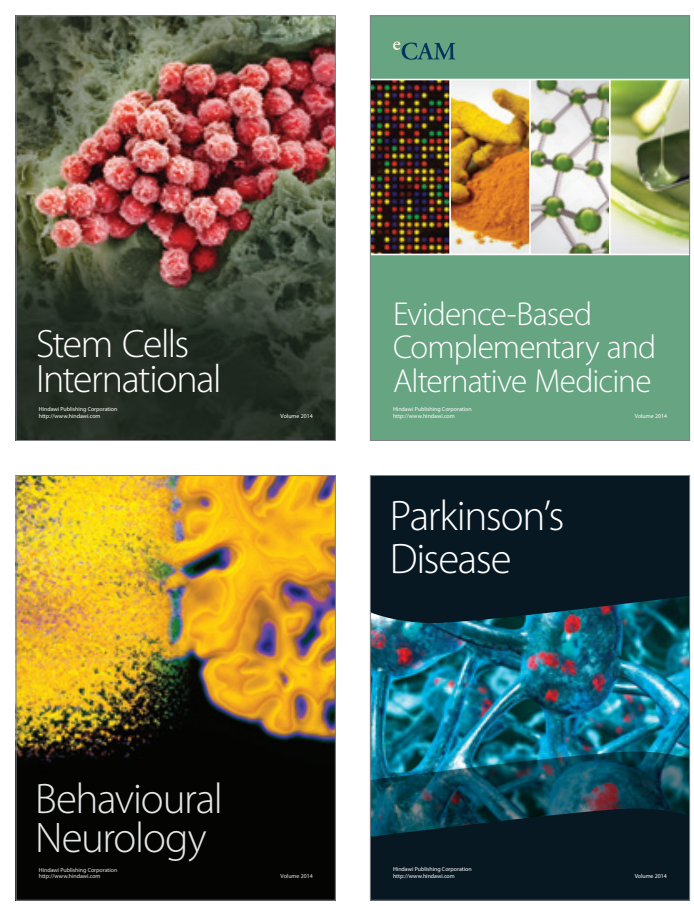

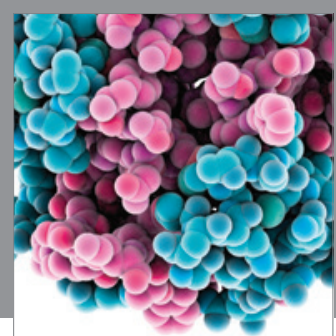

Journal of
Diabetes Research

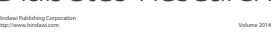

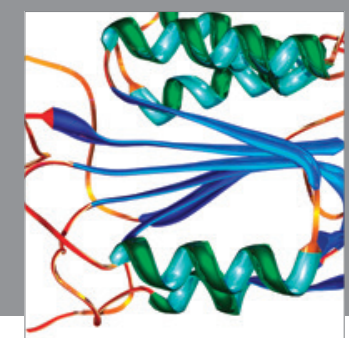

Disease Markers
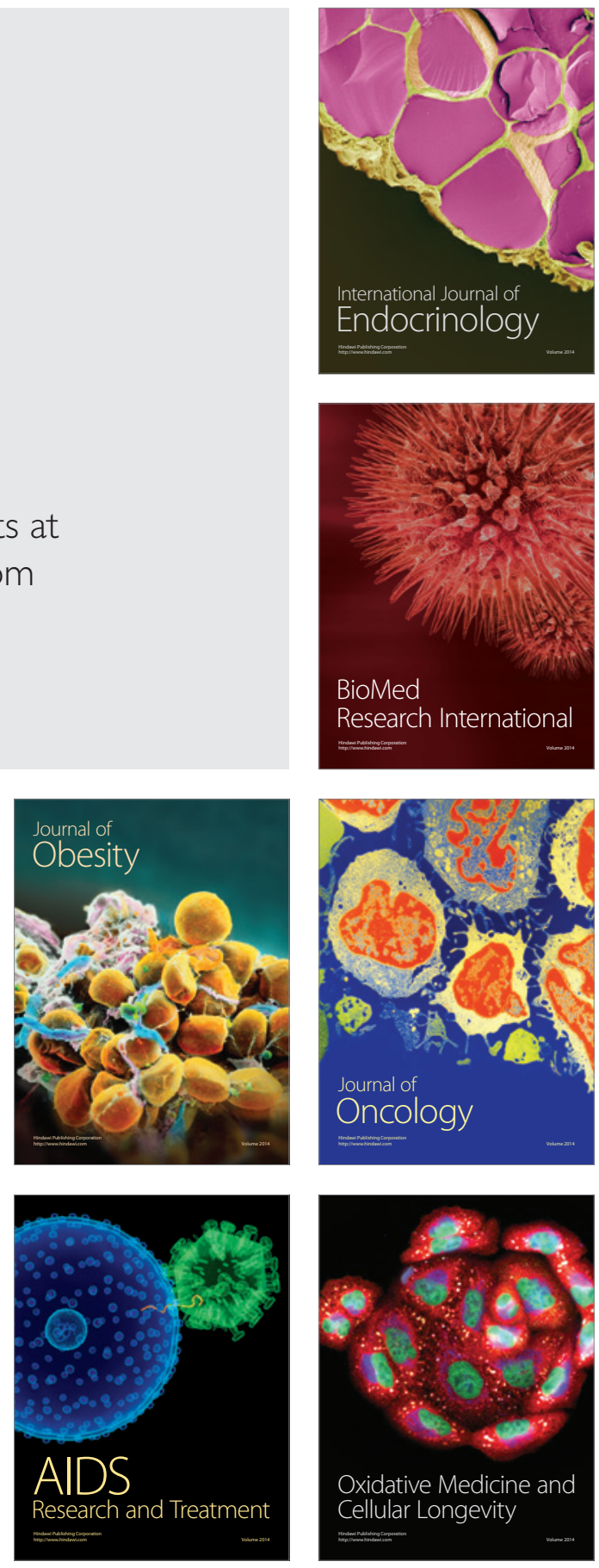